\title{
Monitoring Mediterranean high mountain vegetation in the Sistema Central (Spain): GLORIA project and collateral ecological studies
}

\author{
Alba Gutiérrez Girón \& Rosario G. Gavilán (*)
}

\begin{abstract}
Gutiérrez Girón, A. \& Gavilán, R.G. Monitoring Mediterranean high mountain vegetation in the Sistema Central: GLORIA project and collateral ecological studies. Lazaroa 34: 77-87 (2013).

Mediterranean high-mountain ecosystems are considered to be among the most vulnerable to global change. Nevertheless they are still relatively little known and their structure and function have only been elucidated in last decade. Highmountain environments are also currently target ecosystems for monitoring the changes caused by global change. Specifically the GLORIA project has developed a common long-term survey protocol of plant biodiversity changes in these habitats. Other short-term studies can be combined with long-term protocols and make use of the data already available in order to increase the understanding of these habitats and to predict the future responses of communities to global change. We summarized the most relevant results already achieved with short-term studies using the data recorded with GLORIA protocols in Sistema Central.
\end{abstract}

Keywords: species interactions, plant community ecology, ecological plant strategies, environmental constraints, Sierra de Guarrama, Sierra de Gredos.

Resumen: Gutiérrez Girón, A. \& Gavilán, R.G. Seguimiento de la vegetación de la alta montaña mediterránea en el Sistema Central (España): el proyecto GLORIA y estudios ecológicos relacionados. Lazaroa 34: 77-87 (2013).

\begin{abstract}
A pesar de que los ecosistema de alta montaña Mediterránea se consideran muy vulnerables a los procesos de cambio global, el conocimiento que tenemos es todavía insuficiente; su estructura y funcionamiento han comenzado a ser abordados en la última década. Además, en la actualidad, los ecosistemas de alta montaña son objeto de diferentes estudios de seguimiento de los efectos del cambio global. Una de estas iniciativas es el proyecto GLORIA que ha desarrollado un protocolo de muestreo común para el seguimiento de los cambios de la diversidad vegetal en ecosistemas de alta montaña. Otros estudios a corto plazo pueden combinarse con el seguimiento a largo plazo de estos ecosistemas y emplear los datos recogidos con el protocolo de muestreo GLORIA para profundizar en el conocimiento de estos ecosistemas y poder predecir futuras respuestas de las comunidades frente al cambio global. Resumimos los resultados más relevantes obtenidos utilizando los datos recogidos del proyecto GLORIA en el Sistema Central.
\end{abstract}

Palabras clave: interacciones entre especies, ecología de las comuidades vegetales, estrategias y ecológicas de las plantas, factores ambientales limitantes, Sierra de Guadarrama, Sierra de Gredos.

\section{INTRODUCTION}

High-mountain ecosystems in southern Europe may markely change as a result of climate change, since changes in temperature and precipitation are predicted to be important (SCHÖTER \& al., 2005; NoGUÉs \& al., 2007; ENGLER \& al., 2011). In the study area the combined effect of increasing temperatures and water deficit in sum- mer (GIMÉNEZ-BENAVIDES \& al., 2007; GARCÍACAMACHO \& EsCudero, 2008) may represent a challenge for plant communities living at higher altitudes, since both factors may vary the length of the effective growing season. The recent decrease of plant species richness in mountains of south Europe showed by PAULI \& al. (2012), in a very short period of time (observation period was from year 2001 to 2008), confirms the high sen-

\footnotetext{
* Departamento de Biología Vegetal II. Facultad de Farmacia. Universidad Complutense. E 28040 Madrid, Spain. Email: algutier@ucm.es, rgavilan@ucm.es
} 
sitivity of these ecosystems to global change. During last decade, because the necessity for improve the knowledge of these threatened ecosystems, several studies have started to figure out the dynamic, structure and functional diversity of Mediterranean high mountain plant communities (GAVILÁN \& al., 2002; ESCUDERO \& al., 2004; NAVARRO \& al., 2010; FERNÁNDEZ \& Molero, 2011; GAVILÁn \& al.,2012) and the reproductive strategies of some species living in theses ecosystems (GIMÉNEZ-BENAVIDES, 2006; GARCÍA-CAMACHO, 2009). Nevertheless the weight of environmental factors on the structure and functioning of plant communities are still little studied.

High-mountain ecosystems have recently been systematically surveyed to detect changes caused by global change. The Global Observation Research Initiative in Alpine Environemnts (GLORIA, www.gloria.ac.at) project has developed a standard survey protocol of plant diversity changes in these habitats (PAULI \& al., 2004). GLORIA project protocols provide floristic, climatic and disturbance data of the monitoring areas. Using those data and combining with others like plant traits or soils parameters we have proposed short-term studies in order to increase the understanding of these habitats that may help to predict the future responses of communities to global change. Thus, we summarized the most relevant results already achieved with short-term studies using the data recorded with GLORIA protocols in Sistema Central. Specifically we present an brief summary of the studies of 1) the main environmental gradients relating to plant community composition (GUTIÉRREZ-GIRÓN \& GAVILÁN, 2013), 2) the functional composition of plant communities and its relationships with the environmental factors (GUTIÉRREZ-GIRÓN \& GAVILÁN, 2013) and 3) the spatial pattern and species association in high mountain communities in Sistema Central (GUTIÉRREZ-GIRÓN \& GAVILÁN, 2010).

\section{MATERIAL AND METHODS}

\section{STUDY AREA}

Gloria target region in Sistema Central has been established in two areas, the Sierra de Gua- darrama near Madrid and the Sierra de Gredos western situated. The highest summits in these mountains are Peñalara peak $(2,429 \mathrm{~m}$ asl $)$ in Sierra de Guadarrrama and Almanzor peak $(2,592 \mathrm{~m}$ asl) in Sierra de Gredos. There are few weather stations in the Sistema Central, and most are situated in lowland areas. At the highest weather station, located in the Navacerrada Pass in Sierra de Guadarrama (1890 $\mathrm{m}$ asl), the mean annual precipitation is $1350 \mathrm{~mm}$, with a slightly arid period from May to October, with less than $10 \%$ of the total annual rainfall. In Sierra de Gredos the mean annual precipitation has been estimated at $2000 \mathrm{~mm}$ at $2000 \mathrm{~m}$ asl, of which $77 \%$ falls as snow (PAlaCios \& al., 2011). Mean annual temperature is $6^{\circ} \mathrm{C}$ at $1800 \mathrm{~m}$ asl, (RIVAS-MARTínEZ, 1983). Above $2100 \mathrm{~m}$ asl the snow remains on the ground for less than 40 days at the most exposed sites and more than 220 days in leeward sites (MuÑOZ \& al., 1995; PALACIOS \& al., 2003).

\section{GLORIA sampling protocol}

From summer 2006 to 2008 we have established points for permanent monitoring of high mountain vegetation in six mountain summits of Sistema Central following the GLORIA sampling protocol (PAULI \& al., 2004). Four summits were chosen in Sierra de Guarrama and two summits in Sierra de Gredos: Peñas de la Barranca (2170 m asl), Guarramillas (2210 m asl), Hermana Menor (2270 m asl), Valdemartín (2280 m asl) in Sierra de Guadarrama and Navasomera (2296 m asl) and El Morezón (2362 m asl) in Sierra de Gredos (Table 1).

On every summit, four quadrats of $3 \times 3 \mathrm{~m}$ were set at $5 \mathrm{~m}$ below the peak following the four cardinal points. In each of these, four $1 \times 1 \mathrm{~m}$ plots were sampled. These plots were arranged in the corners of the $3 \times 3 \mathrm{~m}$ grid (Figure 1). The variables slope, percentage cover of vascular plants, bryophytes, lichens, litter, rock, scree, and bare ground were recorded in each $1 \mathrm{x} 1 \mathrm{~m}$ plot. Plots were subdivided into 100 cells of $10 \times 10 \mathrm{~cm}$, and the frequency occurrence of every vascular, lichen and bryophyte species was recorded in 100 cells in each plot. Additionally the frequency of clipped plant shoots and leaves in 100 cells per plot was recorded to measure grazing impact. 
Table 1

Location of summits chosen for GLORIA in Sierra de Guadarrama and Sierra de Gredos (Sistema Central, Spain)

\begin{tabular}{|c|c|c|c|c|c|}
\hline Summit name & Alt. & Coordinates & $\begin{array}{l}\text { Mountain } \\
\text { range }\end{array}$ & Y.S. & Vegetation \\
\hline Peñas de la Barranca & 2170 & 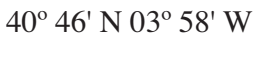 & $\begin{array}{l}\text { Guadarrama } \\
\text { (Madrid) }\end{array}$ & 2006 & $\begin{array}{l}\text { shrub communities of Senecioni- } \\
\text { Cytisetum oromediterranei }\end{array}$ \\
\hline Guarramillas & 2220 & 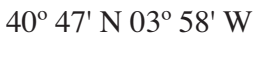 & $\begin{array}{l}\text { Guadarrama } \\
\text { (Madrid) }\end{array}$ & 2006 & $\begin{array}{l}\text { grassland of Hieracio myriadeni- } \\
\text { Festucetum curvifoliae }\end{array}$ \\
\hline Hermana Menor & 2269 & 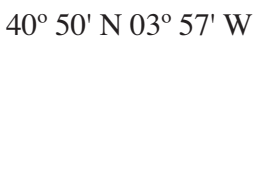 & $\begin{array}{l}\text { Guadarrama } \\
\text { (Madrid) }\end{array}$ & 2007 & $\begin{array}{l}\text { grassland of Hieracio myriadeni- } \\
\text { Festucetum curvifoliae shrub } \\
\text { communities of Senecioni-Cytisetum } \\
\text { oromediterranei and Avenello } \\
\text { ibericae-Juniperetum nanae }\end{array}$ \\
\hline Valdemartin & 2280 & 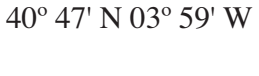 & $\begin{array}{l}\text { Guadarrama } \\
\text { (Madrid) }\end{array}$ & 2006 & $\begin{array}{l}\text { grassland of Hieracio myriadeni- } \\
\text { Festucetum curvifoliae }\end{array}$ \\
\hline Navasomera & 2296 & 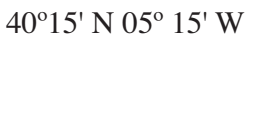 & $\begin{array}{l}\text { Gredos } \\
\text { (Ávila) }\end{array}$ & 2008 & $\begin{array}{l}\text { grassland of Agrostio rupetris- } \\
\text { Minuartetum recurvae (=Sileno- } \\
\text { Jasionetum centralis) }\end{array}$ \\
\hline Morezón & 2632 & 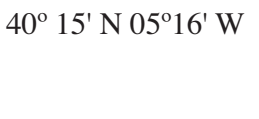 & $\begin{array}{l}\text { Gredos } \\
\text { (Ávila) }\end{array}$ & 2008 & $\begin{array}{l}\text { grassland of Agrostio rupetris- } \\
\text { Minuartetum recurvae (=Sileno- } \\
\text { Jasionetum centralis) }\end{array}$ \\
\hline
\end{tabular}

Their name, altitude (Alt., in masl), geographical coordinates, year of sampling (Y.S.) of vegetation and vegetation type are indicated

Temperature probes with dataloggers (Geoprecision $\mathrm{M} \log 5 \mathrm{~W}$ ) were buried at a depth of $10 \mathrm{~cm}$ in the centre of each $3 \times 3 \mathrm{~m}$ quadrat (Figure 1). A total of four temperature dataloggers were installed per summit.

\section{Collateral Data}

Additionally to the GLORIA protocol we collected compound soil samples near the corners of each $3 \times 3 \mathrm{~m}$ plot in every summits (Figure 1) to

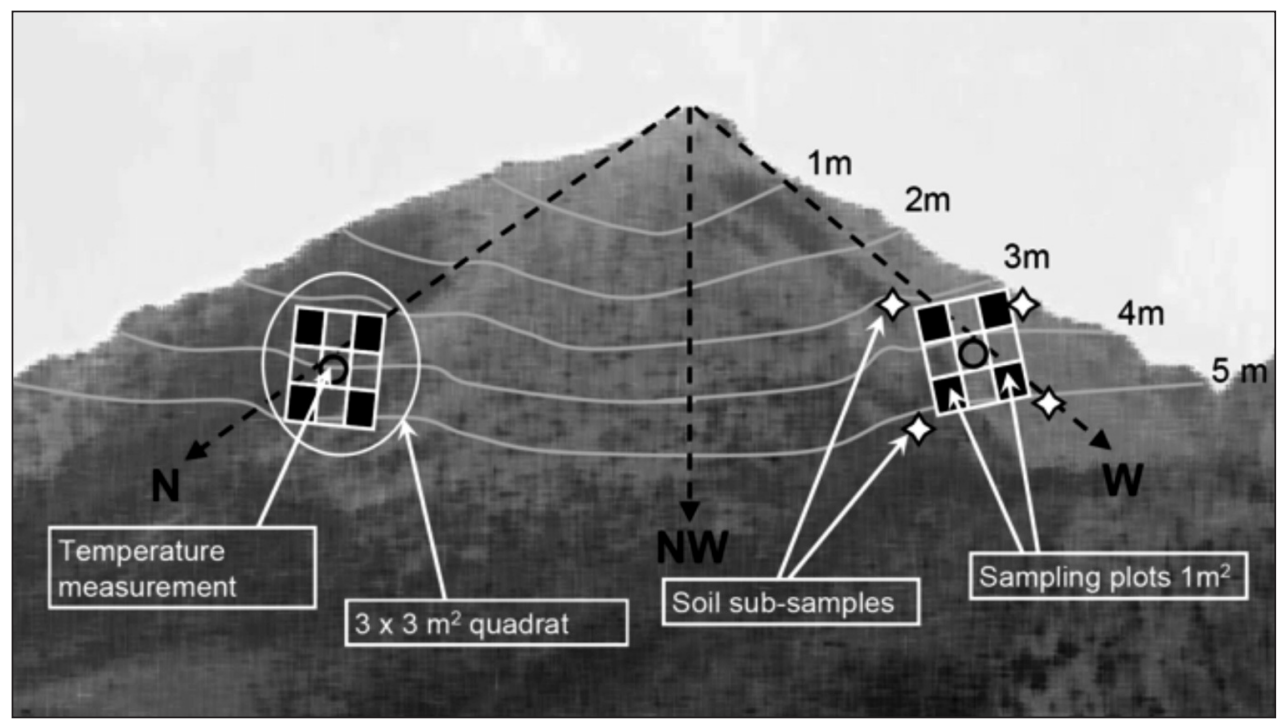

Figure 1. - Diagram shows the sampling design (modified from PAUli \& al., 2004, GutiérREZ-Girón \& GAVILÁN, 2013). 
determine total soil carbon (Csoil) and nitrogen (Nsoil) and soil $\mathrm{pH}$. Climate variables were calculated from hourly temperature records of dataloggers installed on the summits. We calculated snow cover duration (Dsnow), the number of days that soil was frozen (Dice), the number of days with a mean daily temperature $\geq 5^{\circ} \mathrm{C}$ (D5C) as a surrogate of the length of the growing season, mean temperature of the coldest month (Tcold), mean temperature of the warmest month (Twarm) and the monthly mean for the daily soil temperature variation of the warmest month (Trange) as a surrogate of dryness of soil.

Functional traits were determined from plant material of 21 species recollected in the study area and from bibliography following the protocols of CONERLISSEN \& al. (2003). Functional plant traits measured were: height and lateral spread of the plant, leaf mass per area (LMA), leaf dry matter content (DMC), leaf nitrogen concentration, leaf size, seed mass, clonality and woodiness (GuTIÉRREZ-GIRÓN \& GAVILÁN, 2013).

\section{STATISTICAL ANALYSIS}

A forward step-wise RDA analysis was carried out to detect those environmental variables that significantly explained a part of the floristic variation. The significant environmental variables obtained from the RDA analysis were divided into three sets: soil, climate and grazing and a partitioning of variance analysis was performed with RDA to evaluate the relative importance of each set as predictor variables (BOCARD \& al., 1992; LEGENDRE \& LEGENDRE, 1998).

Plant traits were directly related to environmental variables when the three matrices (environment, species and traits) were analysed simultaneously, using the fourth-corner analysis proposed by DRAY \& LEGENDRE (2008). The analysis calculates the statistic $S_{\text {rlq }}$ that measures the link between species traits (Q matrix) and environmental conditions ( $\mathrm{R}$ matrix), mediated through the species matrix (L matrix) (Figure 2). The significance of $S_{\text {rlq }}$ calculated for each pair of environmental variable and plant trait was tested using the permutation model 5 proposed in DRAY \& LEGENDRE (2008) (Figure 2).

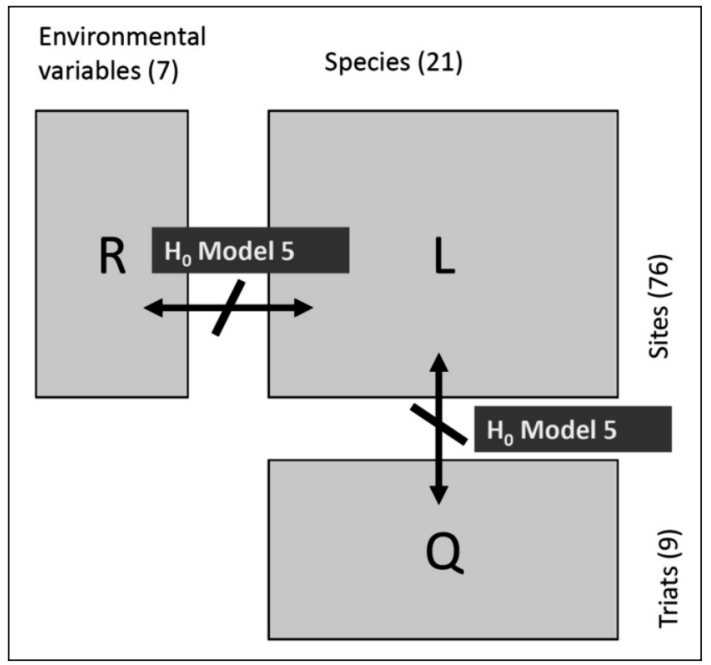

Figure 2. - Diagram of fourth corner analysis (DRAY \& LEGENDRE, 2008). Floristic matrix is used to link and find relationships between traits matrix $(\mathrm{Q})$ and environmental matrix (R). Relationships can be tested with different permutation tests models. $\mathrm{H}_{\mathrm{o}}$ of Model 5 simultaneously breaks the link among matrices.

Spatial pattern of species distribution in the 100 cell frame was analysed using SADIE (Perry, 1998; Perry \& al., 1999). This method uses distance to regularity to measure the total distance involved in moving from the observed spatial arrangements of counts to a regular arrangement. Division of the observed value of $\mathrm{D}$ by the mean value from randomisation gives the index of aggregation $I_{a}$. This index provides information on the overall spatial pattern of species. A sample is clumped if $I_{a}>1$; randomly distributed if $I_{a}=1$, and regularly distributed if $I_{a}<1$.

Positive or negative pairwise species associations were tested using contingency table analysis with Pearson $\chi^{2}$ test on species presence/absence data from each plot cluster $(\mathrm{N}=400)$ and only for species occurring with a frequency per cluster greater than $10 \%$. Phi coefficient of each pairwise association was calculated to measure the degree of association between species. To avoid consider significant associations caused by random, due to the high number of species combinations, only species associations with a $\mathrm{p}<0.01$ for Pearson $\chi^{2}$ test and a Phi value $>0.200$ were considered. Finally the Phi coefficient values between expo- 
sures and summits were tested with Kruskal Wallis and Mann-Whitney U test (SOKAL \& RoHLF, 1995).

Ordinations were made by using CANOCO 4.5 (TER BRAAK \& ŠMilauer, 1998). Fourth-corner analysis and the permutation test were carried out by using the fourth-corner function available in the ADE4 package in R. Other statistical analyses were made using SPSS 15.

\section{RESULTS}

\section{ENVIRONMENTAL FACTORS}

Significant environmental variables after forward step-wise RDA selection were: $\mathrm{pH}$, Nsoil, Tcold, Twarm, Trange, Dsnow, $D_{5 \mathrm{C}}$ and grazing damage. The reduced RDA model built with these eight explanatory variables explained $53.3 \%$ of the total variation of the floristic matrix and was highly significant $(P=0.001$, Monte Carlo test of all constrained axes). The RDA ordination had two main axes of environmental variability. The first axis extended from higher soil $\mathrm{N}$ and grazing disturbance conditions to long snow cover duration. The second axis was related to soil temperature in summer and the surrogate of water availability (i.e. Trange), and $\mathrm{pH}$ (Figure 3). An analysis of the species distribution showed that most woody species, represented by creeping and cushion chamaephytes such as Minuartia recurva, Dianthus gredensis or Thymus praecox, were located at the colder summer sites. Species of lower altitudinal ranges such as Cerastium ramosissimum, Rumex angiocarpus and Agrostis castellana and the psychroxerophilous Festuca curvifolia appeared in warmer and drier summer situations (Figure 3). The cushion species Silene ciliata and $\mathrm{Ja}$ sione crispa and species at lower altitudinal ranges which are frequent in grazing sites such as Paronychia polygonilfolia, Rumex acetosella or Agrostis castellana were related to long-lasting snow conditions, while Armeria caespitosa and Jurinea humilis were related to early melting conditions (Figure 3).

The fraction of variation explained independently by each set of variables and the shared va-

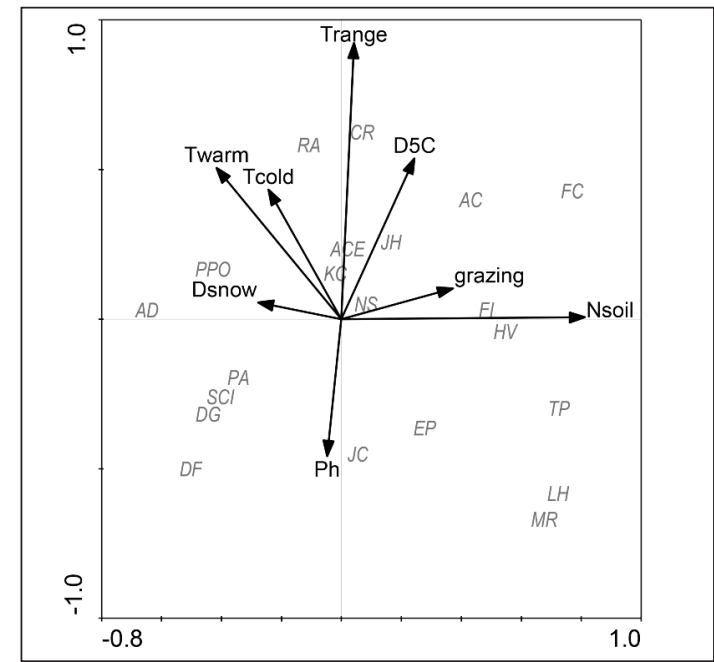

Figure 3. - Biplot of RDA model for species in axis 1 and 2: Species abbreviations: AC, Agrostis castellana; ACE; Armeria caespitosa, AD, Agrostis delicatula; CR, Cerastium ramosissimum; DF, Deschampsia flexuosa subsp. iberica; DG, Dianthus gredensis, EP, Erysimum penyalarense; FC, Festuca curvifolia; FI, Festuca iberica; HV, Hieracium vahlii; JC, Jasione crispa subsp. centralis; JH, Jurinea humilis; KC, Koeleria crassipes; LH, Luzula hispanica; MR, Minuartia recurva; NS, Nardus stricta; PA, Plantago alpina, PPO, Paronychia polygonifolia; RA, Rumex acetosella subsp. angiocarpus; SCI, Silene ciliata; TP, Thymus praecox. Explanatory variable abbreviations: D5C, length of the growing season; Dice, number of days that soil was frozen; Dsnow, snow cover duration; grazing, grazing disturbance; Nsoil, soil nitrogen content, $\mathrm{pH}$, soil $\mathrm{pH}$; Tcold, mean temperature of the coldest month; Twarm, mean temperature of the warmest month; Trange a surrogate of dryness of soil (GUTIÉRREZ-GIRÓN \& GAVILÁN, 2013).

riation was always highly significant $(P<0.01$; Monte Carlo test of all constrained axes). Climate and soil explained most of the floristic variation (Figure 4), while the grazing factor had the least effect (Figure 4).

\section{PlANT TRAITS AND ENVIRONMENTAL FACTORS}

Most of plant traits showed significant relationships with environmental factors (Figure 5). Traits related to resource acquisition such as leaf size and leaf $\mathrm{N}$ concentration showed variation in relation to temperature conditions and water availability in summer, while leaf dry matter con- 


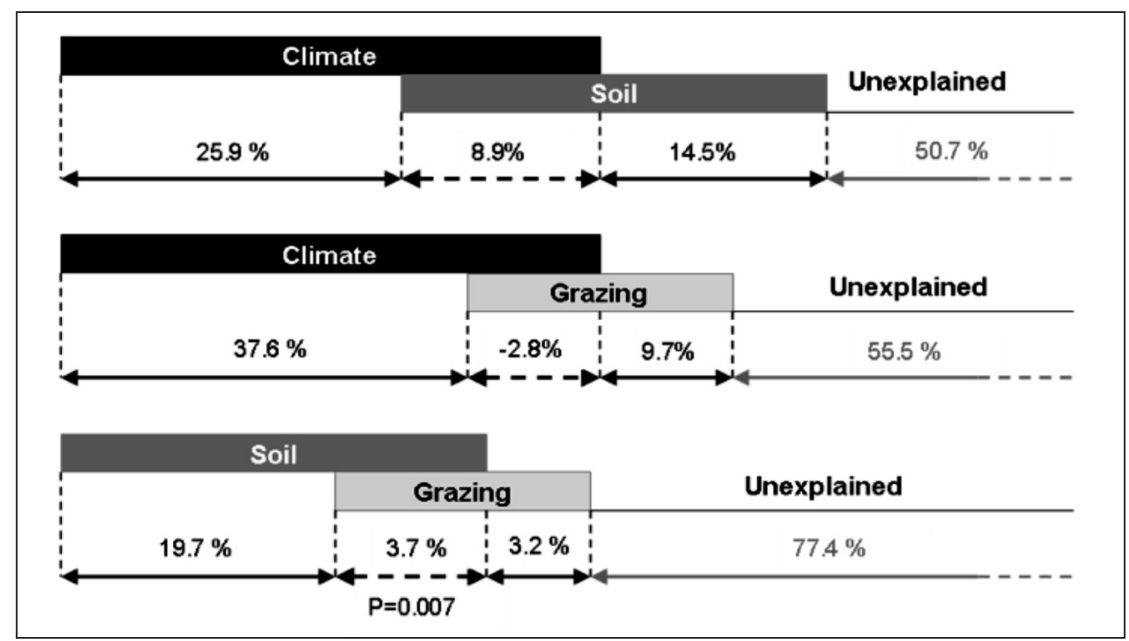

Figure 4. - Partial reduced RDA model. Horizontal bars show total variation explained by each set of variables. Independent and coincident effects are indicated by continuous arrows and dashed arrows respectively. Significance of axes extracted after Monte Carlo Permutation test is $\mathrm{P}=0.001$ unless indicated.

tent was related to water availability and soil development. Seed mass was related to snow cover duration and water availability. Clonality was related to the duration of vegetative period and water availability. Grazing disturbance was related to the mean plant height of species.

\section{SPATIAL PATTERNS AND SPECIES CO-OCCURRENCE}

None of the species presented a regular distribution and most showed a random distribution in the plots. The species that presented an aggregated distribution in at least $50 \%$ of the observations

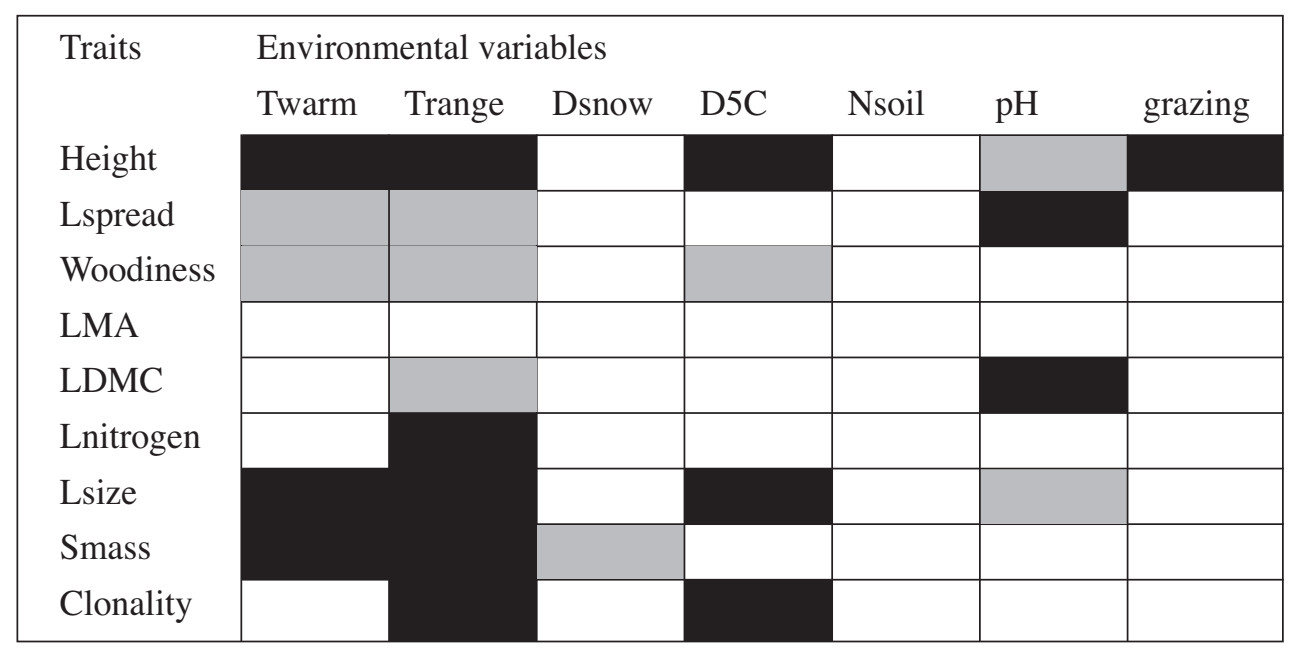

Figure 5. - Summarized results of the fourth-corner analysis relating environmental variables to plant traits. Black and grey squares indicate significant positive relationships, and white squares indicate not significant relationships. Environmental variable abbreviations: Twarm, mean temperature of the warmest month $\left({ }^{\circ} \mathrm{C}\right)$; Trange, mean of daily soil temperature variation of the warmest month $\left({ }^{\circ} \mathrm{C}\right)$; Dsnow, snow cover duration; D5C, length of the growing season; Nsoil, soil nitrogen content; $\mathrm{pH}$, soil pH; grazing, grazing disturbance. Plant trait abbreviations: Height, height of the plant; Lspread, maximum lateral spread of the plant; LMA, leaf mass per area; LDMC, leaf dry matter content; Lnitrogen, leaf nitrogen concentration; Lsize, leaf size; Smass, seed mass. 
were Nardus stricta, Minairtia recurva, Luzula hispanica, Thymus praecox, Jurinea humilis and Rumex acetosella. Comparing the total $I_{a}$ values of each plot we observed that the distribution of $I_{a}$ values in northern exposures was bimodal, indicating greater spatial heterogeneity. Among the three remaining exposures we observed that $I_{a}$ values were significant higher in eastern exposures.

The number of positive associations was always greater than the number of negative associations. There were no significant differences of Phi values among exposures, and between summits. Considering the overall positive associations Festuca iberica, Luzula hispanica and Minuartia recurva established the highest number of positive associations, while Juniperus communis was the most frequent participant in negative associations. Comparing life forms we observed that bryophytes and lichen species were often positively associated, associations among chamaephyte species were unusual and caespitose hemycriptophyte species often participate in positive associations.

\section{DISCUSSION}

Despite de prevaling harsh conditions of high mountain ecosystems they showed an important environmental variability determined by the different weight of several environmental factors such as snow cover duration, windiness, insolation, soil development (FISK \& al., 1998; BRUNN $\&$ al., 2006). The effects of these environmental factors is modulated by topography and thereby High moutain plant communities show a high species turnover along topographical gradients (Kudo \& ITO, 1992; ChOlER, 2005; BRUNN \& al., 2006). In accordance with this we have observed that in high-mountain plant communities in Sistema Central, environmental variability is related to the combination of climate, soil and grazing disturbance factors, which explained an important part of the floristic and functional variability of these plant communities.

In sites with lower summer temperatures and poorly developed soils, most species were woody and have small size, with flat form, and they had smaller and denser leaves. Woodiness and denser leaves indicate a higher longevity and lower turnover rates of their structures (WILSON \& al., 1999; ECKSTEIN \& al., 1999; WRIGHT \& al., 2004). Additionally their flat forms make them less prone to the effects of wind and allow them to retain warmth by acting as heat traps (KÖRNER, 2003). Their small leaf size reduces boundary layer resistance (GATES, 1980) which prevents overheating on sunny days, and can reduce water loss (PARKHURST \& LOUCKS, 1972; GIVNISH, 1987); it also allows them build their canopy early due to the shorter expansion time required for small leaves (Moles \& WeStOBy, 2000). Small leaf size also confers advantages for conserving resources, since small leaves do not require a major investment in supporting structures such as strong stems or leaf ribs (NIINEMETS \& al., 2007), and they are less prone to mechanical damage (DOLPH \& Dilcher, 1980). This combination of plant traits suggests that the least favourable sites for resource acquisition and plant growth were sites with lower summer temperatures, shorter growing seasons and poorly developed soils.

In contrast, at warmer summer sites with more developed soils, species were often grasses, and they have bigger and lighter leaves with higher nitrogen content. These traits have been related to rapid resource acquisition and higher turnover rates of their structures (WRIGHT \& al., 2004). These sites may provide more favourable conditions for temperature, and nutrient resources, but they often appeared to be drier. Thus thermal advantage of warmer sites could offset the disadvantages of drier conditions in warmer sites but only for those species more competitive that can acquire resources more rapid, before the summer drought limits their activity.

Attending to plant traits related to reproduction and establishment we observed that species living in drier sites often were clonal and they had bigger seeds. This combination of traits suggests an ecological strategy of plants to maximize the establishment and survival in drier sites. Larger seeds may enhance seedling establishment against drought hazards (Moles \& Westoby, 2004), while clonal reproduction may be important to enhance the likelihood of persistence after disturbance events (CORNELISSEN \& al., 2003) 
that are possibly caused by more severe drought episodes. In accordance with GIMÉNEZ-BENAVIDES \& al. (2007) and GARCÍA-CAMACHO \& Escudero (2008), these results suggest the importance of water availability in establishment strategies in Mediterranean high-mountain ecosystems.

On the other hand, the weight of grazing disturbance as a constraint was unclear, although grazing affected community composition. Herbivores selected taller plants that in the study area were often graminoids with basal meristems that can be the mechanism to survive grazing damage. Alternatively herbivores could be selecting taller plants that simultaneously had greater leaf nitrogen content and thereby they had more palatable leaves (GuTIÉRREZ-GIRÓN \& GAVILÁN, 2013).

Spatial heterogeneity of a plant community could be driven by several factors such as biotic interactions (CALLAWAY \& al., 1995; FAJARDO \& $a l ., 2008)$, environmental heterogeneity (EHRENFELD \& al., 1997; HutCHINGS \& al., 2003) and patterns of growth or seed dispersal (HERBEN \& al., 1995; NATHAN \& al., 2000). The higher values of $I_{a}$ on eastern slopes and the bimodal distribution of $I_{a}$ values on northern slopes showed a higher spatial heterogeneity of species distributions. Because we considered the overall spatial structure of the community, the higher spatial heterogeneity on northern and eastern exposures may be related with a higher environmental heterogeneity. On northern exposures, environmental heterogeneity may be determined by a lower winter temperatures, and on eastern exposures by a higher grazing disturbance (GUTIÉRREZ \& GAVILÁN, 2010). Both factors have been described previously as causes of environmental heterogeneity (Bliss, 1971; SEEBLOOM \& al., 2005).

The general balance between positive and negative interactions among plant species in alpine environments has been shown to be very important for plant community development (CAVIERES \& al., 2013). As observed in previous studies done in the Sistema Central (GAVILÁn \& al., 2002; ESCUDERO \& al., 2004) positive associations were more frequent than negative associations. Spatial association of species has been showed to be in some cases related to positive species interactions (e.g. CALlaWAY \& al., 1995;
FAJARDO \& al., 2008). Thereby we propose that the frequently aggregated distribution of some of the species is probably related with positive interactions with other species because they differ in life form, ecological requirements, growing pattern and seed dispersal, but all of them participated in positive associations. Other factors that could determine co-occurence of species could be the microhabitat distribution (e.g. SEebloom \& al., 1995; BELL, 2005). Particularly, in the study area, the frequent association of cryptogam species could be related to a shared microhabitat related to soil water conditions.

\section{CONCLUSIONS}

Climatic conditions are the most important environmental constraints. The environmental data available were good predictors of species distribution (total variance explained by RDA model $54 \%$ ). Although high mountain areas are considered less perturbed sites than lowlands in the study area grazing disturbance influence floristic composition.

A range of different strategies for resources acquisition and establishment were observed in the species set in the study. Low temperature during the growing season was observed as a limiting factor to resources acquisition while low water availability during growing season was observed as limiting factor for plant establishment.

For conservation purposes the study of trait composition in relation to environmental factors may be useful in assessing the vulnerability of species according to their functional traits in the face of future ecosystem changes and disturbances. Particularly, since their traits, cushion and other smallleaf woody plants (most particular species), currently living in the coldest sites, could be the most vulnerable group species in a global warming context in Sistema Central. Their low growth rates, frequent lack of clonal reproduction and preference for less developed soils also may make them the most vulnerable to grazing disturbance. In view of this we suggest that future research to monitor the area should consider cushion plants as a particular target group for detecting plant responses under 
global change. Additionally the results suggest that changes on environmental variables may cause changes on spatial pattern of studied plant communities. These changes on spatial structure of plant communities could have effects on species interactions since species associations was partially related to aggregated structure of some species in the plant community.

Finally, we consider that data recorded in GLORIA project for long-term monitoring provides useful information for short-term studies.

\section{ACKNOWLEDGEMENTS}

We thank the staff of the Cuenca Alta del Manzanares Nature Reserve, the Penalara Nature Reserve, and the Gredos Nature Reserve for permission to work in the areas; the coordination team of GLORIA project for the support provided; B. Cobaleda and L. Sanchez for help with the field work. Thanks also to Dr S. Elvira and Dr V. Bermejo for help with leaf parameter measures, to Dr Rubio for help in soil analysis. These studies were supported by the BIOALPI project [MICINN: CGL 2008-901/BOS] of the Spanish Ministry of Science and the pre-doctoral grant [FPU-2005-0999 to AGG] funding by the Spanish Ministry of Education.

\section{REFERENCES}

Bell, G. -2005- The Co-Distribution of Species in Relation to the Neutral Theory of Community Ecology Ecology 86: 1757-1770.

Bliss, LC. - 1971 - Arctic and Alpine Plant Life Cycles. Annu. Rev. Ecol. and Syst. 2: 405-438.

Bocard, D., Legendre, P., Drapeau, P. - 1992 - Partialling out the spatial component of ecological variation - Ecology 73: 1045-1055.

Bruun, H.H., Moen, J., Virtanen. R., Grytnes, J.A., Oskanen, L., Angerbjörn, A. -2006- Effects of altitude an topography on species richness of vascular plants bryophytes and lichens in alpine communities - J. Veg. Sci. 17: 37-46.

Callaway, R. - 1995- Positive interactions among plants- Bot. Rev.61: 306-349.

Cavieres, L., Brooker, R., Butterfield, B., Cook, B., Kikvidze, Z., Lortie, C., Michalet, R., Pugnaire, F., Schöb, C., Xiao, Sa., Anthelme, F., Björk, R., Dickinson, K., Cranston, B., Gavilán, R., Gutiérrez-Girón, A., Kanka, R., Maalouf, J.-P., Mark, A., Noroozi, J., Parajuli, R., Phoenix, G., Reid, A., Ridenour, W., Rixen, C., Wipf, S., Zhao, L., Escudero, A., Zaitchik, B., Aschehoug, E., Lingua, E., Callaway, R. 2013. Facilitative plant interactions and climate simultaneously drive alpine plant diversity - Ecol. Lett. doi: 10.1111/ele.12217

Choler, P. - 2005- Consistent Shifts in Alpine Plant Traits along a Mesotopographical Gradient - Arct. Antarc. Alp. Res. 37: 444-453.

Cornelissen, J.H.C., Lavorel, S., Garnier, E., Díaz, S., Buchmann, N., Gurvich, D.E., Reich, P.B., ter Steege, H., Morgan, H.D., van der Heijden, M.G.A., Pausas, J.G., Poorter, H. - 2003 - A handbook of protocols for standardised and easy measurements of plant functional traits worldwide - Aust. J. Bot. 51: 335-380.

Dolph, G.E.\& Dilcher, D.L. - 1980 - Variation in Leaf Size with Respect to Climate in Costa Rica - Biotropica 12: 91-99.

Dray, S.\& Legendre, P. - 2008 - Testing the species traitsenvironmental relationships: the fourth-corner problem revisited - Ecology 89: 3400-3412.
Eckstein, R.L., Karlsoon, P.S., Weih, M. - 1999- Leaf life span and nutrient resorption as determinants of plant nutrient conservation in temperate arctic-regions - New Phytol. 143: 177-189.

Ehrenfeld, J.G., Han, X., Parsons, W.F.J., Zhu, W. - 1997 On the nature of environmental gradients. Temporal and spatial variability of soils and vegetation in the New Jersey pineland - J. Ecol. 85: 785-798.

Engler, R., Randin, C.F., Thuiller, W., Dullinger, S., Zimmermann, N.E., Araújo, M.B., Pearman, P.B., Le Lay, G., Piedallu, C., Albert, C.H., Choler, P., Coldea, G., De Lamo, X., Dirnböck, T., Gégout, J.-C., Gómez-García, D., Grytnes, J.-A., Heegaard, E., HØIstad, F., NoguésBravo, D., Normand, S., Puscas, M., Sebastiá, M.-T., Stanisci, A., Theurillat, J.-P., Trivedi, M.R., Vittoz, P., Guisan, A. - 2011 - 21st century climate change threatens mountain flora unequally across Europe - Glob. Chang. Biol. 17: 2330-2341.

Escudero, A., Giménez-Benavides, L., Iriondo, J.M., Rubio, A. - 2004 - Patch Dynamics and Islands of Fertility in a High Mountain Mediterranean Community - Arct. Antarc. Alp. Res. 36: 518-527.

Fajardo, A., Quiroz, C.L., Cavieres, L.A. - 2008 - Spatial patterns in cushion-dominated plant communities of the high Andes of central Chile: How frequent are positive associations? - J. Veg. Sci. 19: 87-96.

Fernández Calzado, M.R. \& Molero Mesa, J. -2011 - The cartography of vegetation in the cryoromediterranean belt of Sierra Nevada: a tool for biodiversity conservation - Lazaroa 32: 101-115.

Fisk, M.C., Schmidt, S.K., Seastedt, T.R. - 1998 - Topographic patterns of above-and belowground production and nitrogen cycling in Alpine tundra - Ecology 79: 2253-2266.

García-Camacho, R. \& Escudero, A. -2008- Reproduction of an early-flowering Mediterranean mountain narrow endemic (Armeria caespitosa) in a contracting mountain island - Plant Biol. 11: 515-524.

García-Camacho, R. -2009- Evaluación del éxito reproductivo de Armeria caespitosa en el contexto de cambio 
climático en la alta montaña mediterránea - Mem. Doc. (inéd.). Dpto. Mat. Fís. Apl. Ci. Nat. Univ. Rey Juan Carlos, Móstoles.

Gates, D.M. - 1980 - Biophysical ecology - Springer, New York.

Gavilán, R.G., Sánchez-Mata, D., Escudero, A., Rubio, A. -2002- Spatial structure and interspecific interactions in Mediterranean high mountain vegetation (Sistema Central, Spain) - Isr. J. Plant Sci. 50: 217-228.

Gavilán R.G., Díez-Monsalve E., Izquierdo J.L., GutiérrezGirón A., Fernández-González F. \& Sánchez-Mata D. 2012- An approach towards the knowledge of Iberian high-mountain calcareous grasslands - Lazaroa 33: 43-50.

Giménez Benavides, L. - 2006- Cambio climático en la alta montaña mediterránea. Ecología reproductiva, potencial adaptativo y viabilidad poblacional de Silene ciliata - Mem. Doc. (inéd.). Dpto. Mat. Fís. Apl. Ci. Nat. Univ. Rey Juan Carlos, Móstoles.

Giménez Benavides, L., Escudero, A., Iriondo, J.M. 2007- Reproductive limits of a late-melting highmountain Mediterranean plant along an elevational climate gradient - New Phytol.173: 367-382.

Givnish, T.J. - 1987- Comparative studies of leaf form: assessing the relative roles of selective pressures and phylogenetic constraints - New Phytol. 106: 131-160.

Gutiérrez-Girón, A., Gavilán, R.G. -2010 - Spatial patterns and interspecific relations analysis help to better understand species distribution patterns in a Mediterranean high mountain grassland - Plant Ecol. 210: 137-151.

Gutiérrez Girón, A. \& Gavilán, R.G. -2013- Plant functional strategies and environmental constraints in Mediterranean high-mountain habitats in Central Spain Plant Ecol. Divers. 6: 435-446.

Herben, T., During, H.J., Krahulec, F. - 1995- Spatiotemporal dynamics in mountain grasslands: species autocorrelations in space and time - Folia Geobot. Phyto. 30: 185-196.

Hutchings, M.J., John, E.A., Wijesinghe, D.K. - 2003Toward Understanding the Consequences of Soil Heterogeneity for Plant Populations and Communities Ecology 84: 2322-2334.

Körner, C. -2003-Alpine plant life: functional plant ecology in high mountain ecosystems, 2nd - Springer, Berlin.

Kudo, G. \& Ito, K. - 1992 - Plant distribution in relation to the length of the growing season in a snow-bed in the Taisetsu Mountains, northern Japan - Plant Ecol. 98: 165-174.

Legendre, P. \& Legendre, L. - 1998 - Numerical Ecology - Elsevier, Ámsterdam.

Moles, A.T. \& Westoby, M. - 2000- Do small leaves expand faster than large leaves, and do shorter expansion times reduce herbivore damage? - Oikos 90: 517-524

Moles, A.T. \& Westoby, M. - 2004 - Seedling survival and seed size: a synthesis of the literature - J. Ecol. 92: 372383.

Muñoz, J., Palacios, D., de Marcos, J. - 1995 - The influence of the geomorphologic heritage on present slope dynamics. The Gredos Cirque, Spain - Pirineos 145146: 35-63.

Nathan, R., Muller-Landau, H.C. - 2000 - Spatial patterns of seed dispersal, their determinants and consequences for recruitment - Trends Ecol. Evol. 15: 278-285.

Navarro, T., El Oualidi, J., Taleb, M., Pascual, V., Cabezudo, B., Milla, R. -2010 - Leaf patterns, leaf size and ecologically related traits in high Mediterranean mountain on the Moroccan High Atlas - Plant. Ecol. 210: 275290.

Niinemets, U., Portsmuth, A., Tena, D., Tobias, M., Matesanz, S., Valladares, F. -2007- Do we Underestimate the Importance of Leaf Size in Plant Economics? Disproportional Scaling of Support Costs Within the Spectrum of Leaf Physiognomy - Ann. Bot. London 100: 283-303.

Nogués-Bravo, D., Araújo, M.B., Errea, M.P., MartínezRica, J.P. -2007 - Exposure of global mountain systems to climate warming during the 21st Century Global Environ. Chang. 17: 420-428.

Palacios, D., Andrés, N., Luengo, E. - 2003 - Distribution and effectiveness of nivation in Mediterranean mountains: Peñalara (Spain) - Geomorphology 54: 157-178.

Parkhurst, D.F. \& Loucks O.L. - 1972 - Optimal leaf size in relation to environment - J. Ecol. 60: 505-537.

Pauli, H., Gotffried, M., Hohenwallner, D., Reiter, K., Casale, R., Grabherr, G. - 2004- The GLORIA field manual - Multi-Summit approach. European Commission, Luxembourg

Pauli, H., Gottfried, M., Dullinger, S., Abdaladze, O., Akhalkatsi, M., Alonso, J.L.B., Coldea, G., Dick, J., Erschbamer, B., Calzado, R.F., Ghosn, D., Holten, J.I., Kanka, R., Kazakis, G., Kollár, J., Larsson, P., Moiseev, P., Moiseev, D., Molau, U., Mesa, J.M., Nagy, L., Pelino, G., Puscas, M., Rossi, G., Stanisci, A., Syverhuset, A.O., Theurillat, J.-P., Tomaselli, M., Unterluggauer, P., Villar, L., Vittoz, P., Grabherr, G. -2012- Recent Plant Diversity Changes on Europe's Mountain Summits Science 336: 353-355.

Perry, J.N. - 1998 - Measures of Spatial Pattern for Counts - Ecology 79: 1008-1017.

Perry, J.N., Winder, L., Holland, J.M., Alston, R.D. 1999- Red-blue plots for detecting clusters in count data -Ecol. Lett. 2: 106-113.

Rivas-Martínez, S. - 1983 - Pisos bioclimáticos de España - Lazaroa 5: 33-43

Schröter, D., Cramer, W., Leemans, R., Prentice, I.C., Araújo, M.B., Arnell, N.W., Bondeau, A., Bugmann, H., Carter, T.R., Gracia, C.A., de la Vega-Leinert, A.C., Erhard, M., Ewert, F., Glendining, M., House, J.I., Kankaanpää, S, Klein, R.J.T., Lavorel, S., Lindner, M., Metzger, M.J., Meyer, J., Mitchell, T.D., Reginster, I., Rounsevell, M., Sabaté, S., Sitch, S., Smith, B., Smith, J., Smith, P., Sykes, M.T., Thonicke, K., Thuiller, W., Tuck, G., Zaehle, S., Zierl, B. -2005- Ecosystem Service Supply and Vulnerability to Global Change in Europe - Science 310: 1333-1337. 
Seabloom, E.W., Bjornstad, O.N., Bolker, B.M., Reichman, O.J. - 2005- Spatial signature of environmental heterogeneity, dispersal, and competition in successional grasslands - Ecol. Monogr. 75: 199-214.

Sokal, R.R. \& Rohtl, J. - 1995 - Biometry: the principles and practice of statistics in biological research - Freeman, New York.

ter Braak CJF \& Šmilauer, P. - 1998- CANOCO Reference Manual and User's Guide to Canoco for Windows - Microcomputer Power, Ithaca.

Received: 4 November 2013

Accepted: 9 December 2013
Wilson, P.J., Thompson, K., Hodgson, J.G. -1999- Specific Leaf Area and Leaf Dry Matter Content as Alternative Predictors of Plant Strategies - New Phytol. 143: 155-162.

Wright, I.J., Reich, P.B., Westoby, M., Ackerly, D.D., Baruch, Z., Bongers, F., Cavender-Bares, J., Chapin, T., Cornelissen, J.H.C., Diemer, M., Flexas, J., Garnier, E., Groom, P.K., Gulias, J., Hikosaka, K., Lamont, B.B., Lee, T., Lee, W., Lusk, C., Midgley, J.J. -2004- The worldwide leaf economics spectrum - Nature 428: 821-827. 